DOI: $10.21802 /$ artm.2019.2.10.64.

УДК 616.147.3-007.64-018.2-074

\title{
КЛІНІЧНІ І МОРФОЛОГІЧНІ ПАРАЛЕЛІ ЗМІН СТІНКИ ВАРИКОЗНО РОЗШИРЕНИХ ВЕН У ЖІНОК РЕПРОДУКТИВНОГО ПЕРІОДУ
}

\author{
Б.В. Криса
}

Івано-Франківський національний медичний університет, кафедра хірураї № 1, м. Івано-Франківськ, Украӥна,

ORCID ID: 0000-0002-7822-785X,

e-mail:bodja.ua@gmail.com

Резюме. Мета роботи. Клінічна оцінка мікроструктурних змін венозної стінки при варикозному розширенні вен у жінок репродуктивного періоду.

Матеріали і методи. Дослідження проведено у 2015-2018 роках на базі кафедри хірургії № 1 ІваноФранківського національного медичного університету. Залучено 43 жінки віком від 18 до 39 років. Під час операції брали фрагменти підшкірної вени і фіксували у $10 \%$ розчині нейтрального формаліну. Після зневоднення вени заливали парафіном. Готували зрізи товщиною 5-7 мкм і фарбували гематоксилін-еозином та пікрофуксином за Ван Гізоном. Вивчали зрізи стінки на світловому мікроскопі «CARL ZEISS Axiostar-plus».

Результати та їх обговорення. Візуально видалені вени нерівномірно розширені, у зонах варикозних вузлів витончені. При мікроскопічному дослідженні у початкових стадіях варикозної хвороби $\left(\right.$ клас $\mathrm{C}_{1}-\mathrm{C}_{2}$ за СЕАР) виявляються гіпертрофія м'язової оболонки, запальні інфільтрати, частково заміщені сполучною тканиною. При декомпенсації венозного відтоку (клас $\mathrm{C}_{3}$ за СЕАР) набряк і гіпертрофія стінки змінюються атрофією міозитів, збільшенням кількості сполучної тканини, гіалінозом артеріол мікроциркуляторного русла стінки вени, розростанням грубоволокнистої сполучної тканини, яка заміщає гладком'язові волокна.

Висновки. При прогресуванні варикозного розширення у стінці вени розвиваються дегенеративнодеструктивні зміни у вигляді гіалінозу і заміщення гладком'язових волокон сполучною тканиною. Клінічне прогресування венозної недостатності відповідає варикозній трансформації стінки вени і корелює із прогресуванням деструктивних патогістологічних змін вени, що свідчить про її незворотні морфологічні зміни.

Ключові слова: варикозна хвороба, морфологічні зміни вени.

Вступ. Незважаючи на успіхи у лікуванні хворих з варикозним розширенням вен нижніх кінцівок (ВРВНК), зберігається значна кількість невирішених питань i проблем теоретичного і практичного характеру. Багато незрозумілого залишається у етіопатогенезі варикозної хвороби (BX), який фактично представлений набором факторів ризику, пріоритетність і значення яких може бути різна. Недостатньо вивчені морфофункційні зміни, які розвиваються у стінці вени при ії варикозній трансформації (ВТ) [1].

В останні десятиліття, крім механічних, гемодинамічних та гормональних факторів розвитку BX, значну увагу приділяють вивченню факторів ризику хвороби, які не піддаються корекції, носять вроджений характер і $\epsilon$ тим фоном, на якому при певних умовах розвивається ВТ. Серед них виділяють конституційні (анатомічні) особливості морфологічної будови стінки вен на тлі спадкової дисплазії сполучної тканин, як порушення розвитку органів і тканин у ембріогенезі та в постнатальному періоді $[2,3]$.

Клініко-морфологічними проявами дисплазії сполучної тканини $є$ порушення фізичного розвитку, скелетні аномалії, ураження шкіри органів зору, м'язової, репродуктивної та серцево-судинної системи. Компонентами розвитку ВТ $є$ комплекс патологічних змін, який включає ураження вен (патологічна звивистість, варикозний процес, фіброз судин) та ендотеліальну дисфункцію [4].
Обгрунтування дослідження. У зв'язку 3 тим, що структурні аномалії венозної системи внаслідок слабкості сполучної тканини частіше зустрічаються у жінок, можна вважати гестаційний період у них фактором подвійного ризику реалізації і маніфестації судинних дефектів [5]. Поява ВРВНК свідчить про несприятливий стан стінок венозної системи, який розвивається під час вагітності, та морфологічну дисфункцію їх сполучної тканини [6, 7]. Підтвердженням ролі сполучної тканини у розвитку ВХ $є$ дані про те, що хронічні захворювання вен (ХЗВ) є одним із найчастіших системних проявів патології [8].

Структурна перебудова стінки судин впливає на стан венозної системи нижніх кінцівок, зокрема на iii функціональні можливості, які виявляють за допомогою ультразвукового ангіосканування. Зокрема, у цих пацієнтів визначається клапанна неспроможність остіального клапану з вираженим вертикальним рефлюксом. Проявом клапанної неспроможності перфорантних вен гомілки і стопи є горизонтальні рефлюкси на цих рівнях [9].

Клінічно феномен морфологічної дисплазії сполучної тканини проявляється раннім розповсюдженим ураженням венозної системи, ускладненим протіканням захворювання, частим розвитком рецидивного варикозу після різних типів лікування, що може бути обумовлено морфологічними особливостями будови підшкірних вен $[10,11,12]$. 
Мета дослідження. Клінічна оцінка особливостей мікроструктурних змін венозної стінки при варикозному розширенні вен у жінок репродуктивного періоду.

Матеріали і методи. Дослідження проведено у 2015-2018 роках на базі кафедри хірургії № 1 ІваноФранківського національного медичного університету і клініко-діагностичного центру м. Івано-Франківськ. Залучено 43 жінки віком від 18 до 39 років. Критерії включення - жінки з ВРВНК, які підписали поінформовану згоду про участь в дослідженні. Критерії виключення - жінки 3 тромбофлебітом та відмова від участі у дослідженні. У спостереженнях переважав клас $\mathrm{C}_{1}-\mathrm{C}_{3}$ клінічних ознак ХЗВ за СЕАР.

Для морфологічного дослідження під час операції брали фрагменти великої підшкірної вени довжиною до 1,5 см у ділянці сафено-феморального 3'єднання. Взятий матеріал фіксували 48 годин у 10\% розчині нейтрального формаліну $(\mathrm{pH}=7,0-7,2)$. Після зневоднення фрагменти вени заливали парафіном в апараті карусельного типу «ТМ-4М».

При виготовленні мікропрепаратів використовували стандартні протоколи ущільнення і зневоднення тканин на апараті «Thermo Scientific STP 20» 3 подальшою заливкою в парафін і приготування зрізів товщиною 5-7 мкм на мікротомі «Microm НН 325». Депарафіновані зрізи фарбували гематоксилінеозином, пікрофуксином, за методикою Ван Гізона, для виявлення ступеню склерозу. Патологічні зміни оцінювали напівкількісним методом залежно від ступеня вираження флебосклерозу (слабо, помірно, різко виражені зміни). Мікрофотографування гістологічних зрізів стінки вен виконували на світловому мікроскопі «CARL ZEISS Axiostar-plus» із збільшенням 75-600 цифровою фотокамерою «Сanon camPS».

Гістологічні препарати виготовлені у патогістологічній лабораторії кафедри патоморфології та судової медицини Івано-Франківського національного медичного університету i консультовані доктором медичних наук, професором I.О. Михайлюком.

Результати дослідження. При розвитку ВРВНК візуально видалені вени нерівномірно розширені 3 вузлуватими витонченими вип'ячуваннями стінки - варикозними вузлами. Вени видовжені, а у зонах варикозних вузлів - скручені із витонченою стінкою, що разом із їх розширенням $є$ наслідком хронічної гіперволемії і/або венозної гіпертензії.

Видовження судини при мікроскопічному дослідженні супроводжується збільшенням кількості поздовжніх м'язових волокон та гіпертрофією. Стадія компенсації варикозних змін (до початку розвитку стійкого набряку тканин) характеризується гіпертрофією м'язової оболонки, фіброеластозом інтими, утворенням островків лейоміоцитів, які з часом перероджуються у запальний інфільтрат і заміщуються сполучною тканиною. При декомпенсації венозного відтоку набряк навколишніх тканин i гіпертрофія стінки змінюються дистрофією, атрофією міозитів, збільшенням кількості сполучної тканини.

При дослідженні фрагментів проксимального відділу великої підшкірної вени вен жінок із ВРВНК незначні морфологічні зміни у препаратах були вияв- лені у 8 спостереженнях (18,6\%). У жінок цієї групи спостерігали варикозне розширення вен без клінічних ознак хронічної венозної недостатності. Мікроскопічні зміни стінки судини у них характеризувались незначними змінами строми і м'язової тканини. У цілому мікроструктура стінки вени була збережена, спостерігалось потовщення вени за рахунок набряку (рис. $1)$.

Такий стан визначається в літературі як міжм'язовий (інтерфасцикулярний) фіброз, при якому товщина стінки фактично не змінюється, а лише проходить рівномірне ущільнення сполучнотканинних прошарків між пучками м'язових волокон [1]. Такі зміни зустрічаються при компенсованих формах ВРВНК (клас $\mathrm{C}_{1}-\mathrm{C}_{2}$ клінічних ознак ХЗВ за СЕАР). Виявлені зміни морфологічної картини будови стінки великої підшкірної вени характерні для початкової стадії розвитку ХЗВ. Аналіз результатів клінічних обстежень даних 8 пацієнток це підтверджує. Всі вони були у віці до 40 років і звернулись за медичною допомогою 3 приводу ВРВНВ із компенсованими іiі проявами, а ХВН у них не переважала клас $\mathrm{C}_{2}$.

При гістологічному дослідженні 23 препаратів (53,5\%) проксимального відділу великої підшкірної вени у жінок із субкомпенсованими проявами венозної недостатності, які відповідали класу $\mathrm{C}_{2}$ клінічних ознак ХЗВ за СЕАР, були зареєстровані значні зміни морфологічної будови у вигляді гіпертрофії гладком'язових елементів і помірного флебосклерозу, який являв собою подальший етап розвитку ХЗВ. Зміни, виявлені у гістологічних препаратах, були неоднорідними, постійно виявлялась гіпертрофія гладких м'язів. Разом з фіброзом колагенового каркасу і змінами в стромі, виявляли множинне вростання колагенових структур у гладком'язеві пучки (Рис. 2).

Перебудова медії характеризувалась атрофічними змінами еластичного каркасу. Склеротичні зміни у стромі стінки вен мали схильність до утворення обмежених рубцевих полів, у яких спостерігалась атрофія гладком'язевих волокон, оточених рубцевою тканиною. Розвивалась гіпертрофія ендотеліальної оболонки, порушення мікроциркуляторного русла стінки вени, венозний застій і мікрокрововиливи у стінці. У сполучнотканинних прошарках виявляли відкладання гіаліну, поєднане із діеластозом (рис. 3).

У 12 жінок $(27,9 \%)$ із вираженими проявами $\mathrm{BX}$ (клас $\mathrm{C}_{3}$ клінічних ознак ХЗВ за СЕАР) виявлено множинні вогнища склерозу варикозно трансформованої стінки. У гістологічних препаратах цієї групи хворих звертала увагу перебудова середньої оболонки вени 3 перевагою склеротичних змін. Стінка вени втрачала свої риси: від інтими до адвентиції розміщувалась щільна волокниста сполучна тканина, у якій неоднорідно розміщувались залишки атрофованої гладком'язової тканини. Відмічався гіаліноз артеріол різного калібру мікроциркуляторного русла стінки вени та розростання в них сполучної тканини. Такий вид перебудови стінки вени можна характеризувати як рубцевий склероз із гіалінозом і атрофією гладком'язової тканини $з$ наступним її витонченням і розширенням (рис. 4). 
Таким чином, патоморфологічній картині ураження стінки великої підшкірної вени відповідають процеси, які характеризують прогресування варикозної хвороби і хронічної венозної недостатності: від потовщення стінки вени за рахунок іiі набряку i міжм'язового фіброзу при початкових проявах варикозної хвороби і компенсованих порушеннях венозного відтоку до вираженої сполучнотканинної перебудови всієї стінки вени, заміщення гладком'язового компоненту щільною волокнистою сполучною тканиною і гіалінозом артеріол мікроциркуляторного русла стінки вени при суб- і декомпенсованих порушеннях венозного відтоку із нижніх кінцівок.

Обговорення результатів. Враховуючи дані клінічних і морфологічних досліджень стінки великої підшкірної вени у жінок репродуктивного періоду, оперованих з приводу ВРВНК, можна припустити, що дегенеративно-дистрофічні зміни у вигляді гіалінозу і заміщення гладком'язових волокон сполучною тканиною 3 наступним флебосклерозом супроводжують прогресування хронічної венозної недостатності. Ці зміни погіршують функціональні властивості стінки вени і прискорюють декомпенсацію хронічної венозної недостатності.

У цілому у патоморфологічній картині ураження великої підшкірної вени при її варикозній трансформації спостерігаються наступні процеси: гіпертрофія гладких м'язових волокон і набряк тканин стінки вени із слабо вираженим флебосклерозом та збереженою структурою гладком'язових волокон при початкових і компенсованих формах варикозної хвороби.

Наростання декомпенсації венозного відтоку і прогресування венозної недостатності мікроскопічно відзначається прогресуванням гіпертрофії стінки вени за рахунок заміщення гладком'язових волокон гіаліном і розростання сполучної тканини. В подальшому розвивається гіаліноз артеріол мікроциркуляторного русла стінки вени і розростання грубоволокнистої

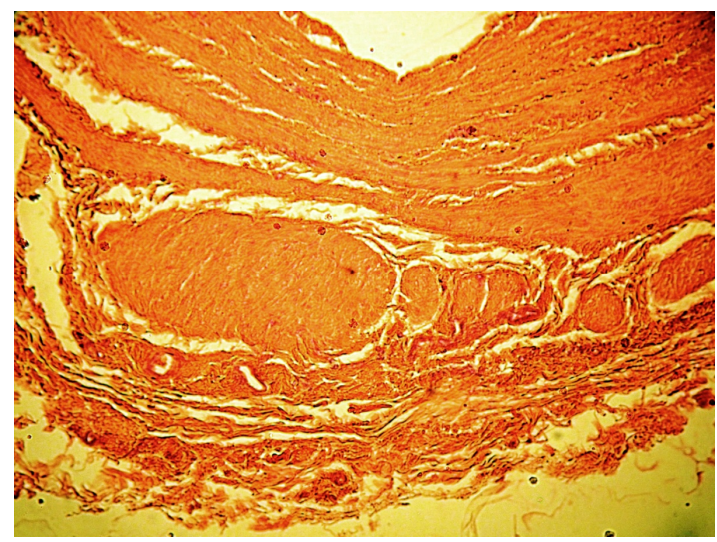

Рис. 1. Гіпертрофія гладких м'язових волокон і набряк тканин стінки вени, слабо виражений флебосклероз проксимального відділу великої підшкірної вени. Структура гладком'язових волокон збережена.

Фарбування гематоксиліном і еозином. Збільшення $\times 375$. сполучної тканини із практично повним заміщенням гладком'язових волокон.

Узагальнюючи отримані дані, можна припустити, що морфологічні зміни у венозній стінці при ВРВНК у жінок репродуктивного періоду, які мали одну або більше вагітностей, можуть розвиватись ще до або під час вагітностей, а відсутність повної інволюції варикозу або його прогресування після пологів можна пояснити подальшим розвитком деструктивних морфологічних змін.

Це припущення відповідає сучасним поглядам, згідно з якими вважається, що під час вагітності головним етіологічним фактором розвитку ВХ $є$ вроджена дисплазія сполучної тканини, яка викликає морфологічну перебудову венозної стінки і появу спадково запрограмованого розвитку патології, що проявляється слабкістю елементів судини, зокрема іiі сполучної тканини і гладкої мускулатури, дисфункцією і пошкодженням ендотелію, пошкодженням венозних клапанів, порушенням мікроциркуляції в стінці вени $[1,9]$. Крім того, компресія нижньої порожнистої i здухвинних вен маткою, яка збільшується, веде до зростання тиску у венах нижніх кінцівок і прискорює розвиток $\mathrm{XBH}$.

Важливим етіологічним чинником у жінок $є$ ріст концентрації прогестерону, який починається у першому триместрі. Прогестерон стимулює дегенеративно-дистрофічні зміни у колагенових і еластичних волокнах, сприяє зниженню тонусу стінок вен і розширенню їх просвіту, що веде до розвитку клапанної недостатності і декомпенсації венозного відтоку [4, 5, $8]$.

Таким чином, дослідження морфофункційних змін, які проходять у стінці вени при прогресуванні ВРВНК, розширює уявлення про ланки етіології $\mathrm{i}$ патогенезу хронічних захворювань вен нижніх кінцівок, зокрема у жінок репродуктивного періоду, і дозволяє рекомендувати оптимальні методи профілактики і лікування на різних стадіях захворювання.

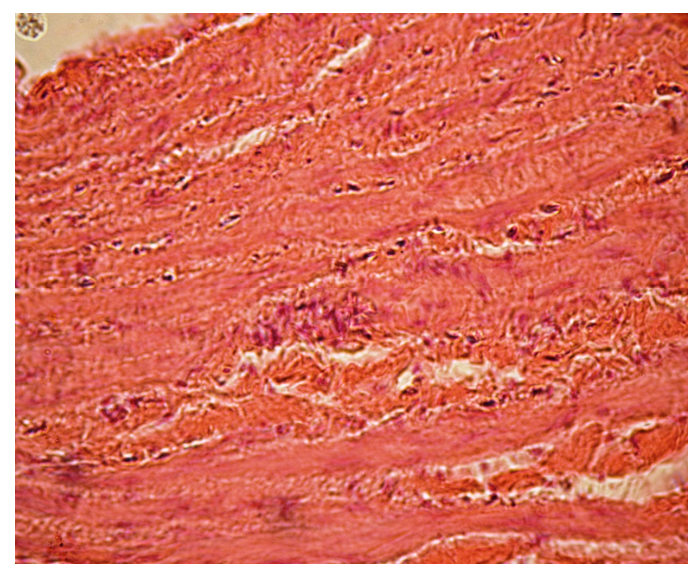

Рис. 2. Виражений набряк стінки вени, крововиливи та венозний застій у стінці, гіпертрофія i фрагментування гладком'язових волокон, порушення мікроциркуляторного русла стінки вени. Фарбування гематоксиліном і еозином. Збільшення $\times 375$. 


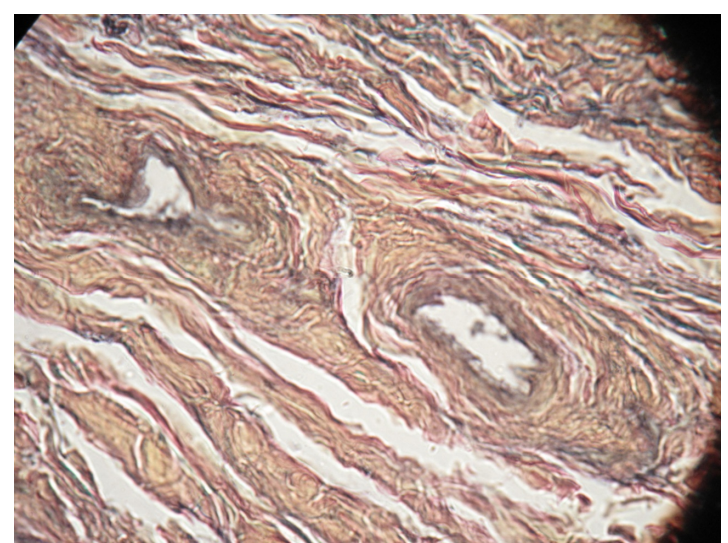

Рис. 3. Гіпертрофія стінки вени за рахунок вираженого заміщення гладком'язових волокон гіаліном і розростання сполучної тканини. Гіаліноз артеріол мікроциркуляторного русла стінки вени. Фарбування пікрофуксином за методикою Ван Гізона. Збільшення - $\times 600$.

\section{Висновки:}

1. У міру прогресування варикозного розширення підшкірних вен нижніх кінцівок у стінці вени розвиваються дегенеративно-деструктивні зміни у вигляді гіалінозу і заміщення гладком'язових волокон грубоволокнистою сполучною тканиною, що погіршує функціональні властивості стінки вени і прискорює розвиток декомпенсації хронічної венозної недостатності.

2. Клінічне прогресування хронічної венозної недостатності при варикозної хворобі відповідає макроструктурній варикозній трансформації стінки вени і корелює із прогресуванням деструктивних патогістологічних змін стінки вени, що свідчить про незворотні морфофункційні зміни вени.

\section{References:}

1. Mel'nikov MV, Yerofeyev NP, Shchiraya YeA, Vinnichuk SA, Turina AV. Patomorfologicheskiye i biomekhanicheskiye izmeneniya stvola bol'shoy podkozhnoy veny pri varikoznoy bolezni. Regionarnoye krovoobrashcheniye i mikrotsirkulyatsiya. 2014;12(4):5660.

2. Potapov MP, Staver YeV. Kliniko-laboratornyye kriterii nespetsificheskoy displazii soyedinitel'noy tkani kak prediktory retsidiva varikoznoy bolezni nizhnikh konechnostey. Flebologiya. 2013;4:25-9.

3. Nuyting L, Freund M, Lagae L, Pierard G, HrmannsLe T, De Paepe A. Classical Ehlers-Danlos Syndrome Caused by a Mutation in Type I Collagen. Am. J. Hum Genet. 2000; 66:1398-402.

4. Nazarenko LH. Dysplaziya spoluchnoyi tkanyny: rol' v patolohiyi lyudyny i problemakh hestatsiynoho periodu (Ohlyad). Zhinochyy likar. 2010;1:42-8.

5. Mozes VG, Mozes KB. Klinicheskiye proyavleniya sistemnogo porazheniya soyedinitel'noy tkani u zhenshchin rannego reproduktivnogo vozrasta s varikoznym rasshireniyem ven. Byulleten' sibirskoy meditsiny. 2006;1:87-90.

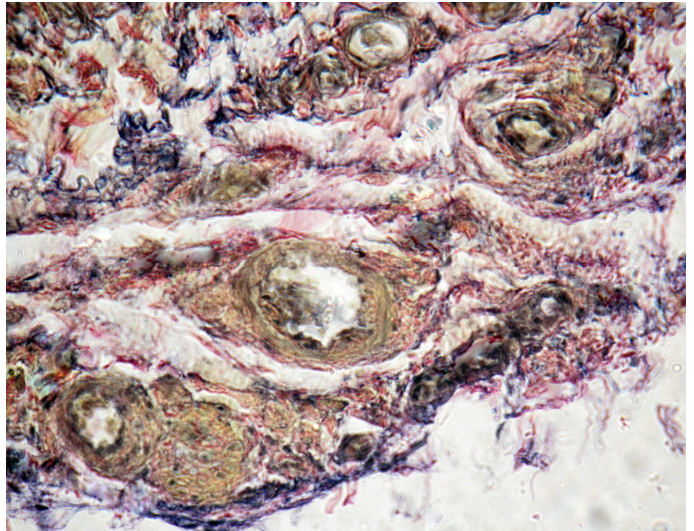

Рис. 4. Виражений гіаліноз артеріол мікроциркуляторного русла стінки вени. Розростання грубоволокнистої сполучної тканини із тотальним заміщенням нею гладком'язових волокон.

Фарбування пікрофуксином за методикою Ван Гізона. Збільшення $-\times 600$.

6. Hoshchyns'kyy VB, Prodan AM, Pyatnychka OZ. Morfolohichni, klinichni ta biokhimichni paraleli dysfunktsiyi spoluchnoyi tkanyny $u$ khvorykh na varykoznu khvorobu nyzhnikh kintsivok. Naukovyy visnyk Uzhhorods'koho universytetu, seriya «Medytsyna». - 2014;1(49):59-64.

7. Krysa, J, Jones GT, van Rij AM. Evidence for a genetic role in varicose veins and chronic venous insufficiency. Phlebology. 2012; 27(7):329-35.

8. Yupatov YeYU. Khronicheskaya venoznaya nedostatochnost' i beremennost'. Prakticheskaya meditsina. 2009;34(2):44-8.

9. Dzyubanovs'kyy IYA, Prodan AM, Pyatnochka OZ. Ul'trazvukovi zminy pry varykozniy khvorobi nyzhnikh kintsivok na foni dysplaziyi spoluchnoyi tkanyny. Ukrayins'kyy zhurnal khirurhiyi. 2017;2(33):21-7.

10. Hoshchyns'kyy VB, Havrylyuk MV, Pyatnychko OZ. Varykoznyy syndrom na grunti nedyferentsiyovanoyi dysplaziyi spoluchnoyi tkanyny, yak prychyna pislyaoperatsiynoho retsydyvu varykoznykh ven. Naukovyy visnyk Uzhhorods'koho universytetu. «Medytsyna». 2012;45(3):24-6.

11. Mashchenko YUV, Tsarev OA, Maslyakova GN, Tsareva MO. Morfologicheskiye osobennosti bol'shoy podkozhnoy veny u bol'nykh varikoznoy bolezn'yu assotsiirovannoy $\mathrm{s}$ displaziyey soyedinitel'noy tkani. Sovremennyye problemy nauki i obrazovaniya. 2014;6:47.

12. Lee BB. Current concept of venous malformation (VM). Phlebolymphology. 2003;43:197-203.

УДК 616.147.3-007.64-018.2-074

КЛИНИЧЕСКИЕ И МОРФОЛОГИЧЕСКИЕ ПАРАЛЛЕЛИ ИЗМЕНЕНИЯ СТЕНКИ ВАРИКОЗНО РАСШИРЕННЫХ ВЕН У ЖЕНЩИН РЕПРОДУКТИВНОГО ПЕРИОДА

Б.В. Крыса 
Ивано-Франковский нащиональный медицинский университет, кафедра хирургии № 1,

2. Ивано-Франковск, Украина,

ORCID ID: 0000-0002-7822-785X,

e-mail:bodja.ua@gmail.com

Резюме. Цель работы. Клиническая оценка микроструктурных изменений венозной стенки при варикозном расширении вен у женщин репродуктивного периода.

Материалы и методы. Исследование проведено в 2015-2018 годах на базе кафедры хирургии № 1 Ивано-Франковского национального медицинского университета. Привлечено 43 женщины в возрасте от 18 до 39 лет. Во время операции делали забор фрагмента подкожной вены и фиксировали в $10 \%$ растворе нейтрального формалина. После обезвоживания вену заливали парафином. Готовили срезы толщиной 5-7 мкм, окрашивали гематоксилин-эозином, пикрофуксином по Ван Гизону и изучали на световом микроскопе.

Результаты и их обсуждение. Визуально удалённые вены расширены и истончены в зонах варикозных узлов. При микроскопическом исследовании в начальных стадиях варикозной болезни (класс $\mathrm{C}_{1}-\mathrm{C}_{2}$ по СЕАР) развивается гипертрофия мышечной оболочки, воспалительные инфильтраты, частично замещённые соединительной тканью. При нарастании декомпенсации венозного оттока (класс $\mathrm{C}_{3}$ по СЕАР) развивается атрофия миозитов и гиалиноз артериол микроциркуляторного русла стенки вены, увеличивается количество соединительной ткани, разрастается грубоволокнистая соединительная ткань, которая замещает гладкомышечные волокна.

Выводы. При прогрессировании варикозного расширения в стенке вены развиваются дегенеративно-деструктивные изменения в виде гиалиноза и замещения гладкомышечных волокон соединительной тканью. Клиническое прогрессирование венозной недостаточности соответствует варикозной трансформации стенки вены и коррелирует с прогрессированием деструктивных патогистологических изменений вены, что свидетельствует о необратимых морфологических изменениях.

Ключевые слова: варикозная болезнь, морфологические изменения вены.

UDC 616.147.3-007.64-018.2-074

CLINICAL AND MORPHOLOGICAL PARALLELS OF CHANGES IN VARICOSE VEIN WALL IN WOMEN OF CHILDBEARING AGE

\section{B.V. Krysa}

Ivano-Frankivsk National Medical University, Department of Surgery No. 1, Ivano- Frankivsk, Ukraine, ORCID ID: 0000-0002-7822-785X,

e-mail:bodja.ua@gmail.com
Abstract. Research objectives. Clinical assessment of microstructural changes in the venous wall at varicose veins in women of childbearing age.

Materials and methods. The research was conducted in 2015-2018 based on the Chair of Surgery No. 1 of Ivano-Frankivsk National Medical University. Fortythree women aged from 18 to 39 were involved. During the operation, we took fragments of the subcutaneous vein, which was fixed in the neutral formalin solution. The veins were filled with paraffin after dehydration. The wall sections were stained with hematoxylin-eosin and picro-fuchsin according to Van Gieson and studied on a light microscope CARL ZEISS Axiostar-plus.

Results and their discussion. During the research, minor morphological changes have been found in eight observations $(18.6 \%)$. The women of this group had a varicose vein disease of $\mathrm{C}_{1}-\mathrm{C}_{2}$ clinical class according to CEAP. Microscopic changes were characterized by minor changes in stroma and muscle tissue, the wall structure is saved. This condition is determined as an intermuscular fibrosis, which is a feature of initial manifestations. Analysis of the clinical research results confirms this. All patients were under the age of 40 and sought medical attention with compensated manifestations of disease.

At the histological study of 23 drugs (53.5\%), women with $\mathrm{C}_{2}$ clinical class according to CEAP had significant changes in the form of hypertrophy of smooth muscles and moderate phlebosclerosis. The sclerotic scarry fields and smooth muscle atrophy with microbleeding have been formed in the vein wall.

Twelve women $(27.9 \%)$ with $\mathrm{C}_{3}$ clinical class according to CEAP had the multiple sclerosis centers of a varicose transformed vein that lost its features: a connective tissue was with the remains of smooth muscles from the intima to adventitia. We noted the hyalinosis of microvasculature arterioles of the vein wall. This reconstruction of the vein wall can be characterized as a scary sclerosis with hyalinosis and atrophy of smooth muscles.

Thus, the pathomorphological presentation of varicose vein wall disease belongs to processes that characterize the progression of varicose vein disease and chronic venous insufficiency: from thickening of the vein wall due to edema and intermuscular fibrosis at the initial manifestations of disease to severe connective tissue reconstruction of the entire wall, replacement of the muscular component with the dense fibrous connective tissue and hyalineinosis of the walls of arterioles of the microcirculatory bloodstream at decompensation of the venous return.

Conclusions. The degenerative and destructive changes in the form of hyalinosis and replacement of smooth muscle fibers with connective tissue develop at the varicose vein wall progression. Clinical progression of venous insufficiency corresponds to varicose vein wall transformation and correlates with the progression of destructive histological changes in the vein, indicating the irreversible morphological changes.

Keywords: varicose vein disease, morphological changes in the veins.

Стаття надійшла в редакцію 02.07.2018 р. 